\title{
CLIL Method to Increase Students' Motivation in Studying Mathematics at Higher Technical School
}

\author{
Kateryna Vlasenko ${ }^{1}$, Olena Chumak ${ }^{2, *}$, Irina Sitak ${ }^{3}$, Tetiana Kalashnykova ${ }^{4}$, Vitaliy Achkan ${ }^{5}$ \\ ${ }^{1}$ Department of Higher Mathematics, Donbass State Engineering Academy, Ukraine \\ ${ }^{2}$ Department of General Engineering, Donbas National Academy of Civil Engineering and Architecture, Ukraine \\ ${ }^{3}$ Department of Mathematics and Computer Technologies, The Institute of Chemical Technologies (the town of Rubizhne) of the East \\ Ukrainian Volodymyr Dahl National University, Ukraine \\ ${ }^{4}$ Department of Humanitarian Training, Donbas National Academy of Civil Engineering and Architecture, Ukraine \\ ${ }^{5}$ Department of Mathematics and Methods of Learning Mathematics, Berdyansk State Pedagogical University
}

Received October 21, 2019; Revised December 25, 2019; Accetped December 30, 2019

Copyright $\bigcirc 2020$ by authors, all rights reserved. Authors agree that this article remains permanently open access under the terms of the Creative Commons Attribution License 4.0 International License

\begin{abstract}
The article looks into the issue of improving students' motivation during the study of Mathematics. This study focuses on the implementation of the $\mathrm{C} 2$ model within CLIL-approach while teaching Elementary Mathematics to students in higher technical educational institutions. The research analyzed the influence of teaching methods, modes, and resources, which can be used to support the teaching of mathematical discipline in English and improve students' motivation. The paper describes the types of students' activities in the course of the developed classes. The study presents the types of tasks, content support, and language support that contribute to student motivation, student-teacher interaction as well as the development of thinking, reasoning skills. The article shows consolidated activities of all the teachers engaged in teaching in experimental groups, and aimed at developing the syllabus and "bank" of learning support materials. This paper also discusses the requirements and recommendations, complying with which contributed to the positive dynamics in students' achievement motives, their cognitive motives, learning, and vocational motives. There was ground to conclude that the conducted course in Elementary Mathematics on the basis of the CLIL method had a positive effect on improving students' interest in mathematics as well as their motivation.
\end{abstract}

Keywords CLIL-approach, Teaching Elementary Mathematics, Students' Motivation

\section{Introduction}

The increase in higher school students' interest in mathematics is directly dependent on their level of motivation. OECD [28] proposes strategies that can help to raise students' motivation while studying Mathematics in countries where it is critically low. Among all the strategies, the use of the approach that provides for the integration of other disciplines with mathematics stands out. While choosing the accompanying discipline, it is recommended to pay attention to those that are popular with students. For the time being, a foreign language is extremely popular and in great demand, because everyone is aware of the fact that without a foreign language, especially English, it is impossible to get a decent well-paid job and to build a successful career. With this in mind, we have determined the nature of such approaches of teaching mathematics that use a foreign language as the language of the learning process and decided to focus on CLIL-approach (Content and Language Integrated Learning) developed by D. Marsh [22].

We have analyzed the experience of the scientists who have applied the CLIL-approach to different disciplines. Y. Bystray, L. Belova, O. Vlasenko, M. Zasedateleva, T. Shtykova [4] presented for consideration a pedagogical project developed with account for the requirements of CLIL-approach by the history department lecturers of humanities and pedagogy university. G. Vollmer, H. Johannes, L. Heine, R. Troschke, D. Coetzee, V. Kuttel [39] considered the application of the CLIL method when teaching geography in Grade 10 of secondary schools in Germany. O. Kulyk [17] presented the Ukrainian experience of teaching analytical philosophy in English using CLIL-approach. The researchers have highlighted the difficulties that arise while implementing this technology. Among the problems identified M. Hajer and L. Maaike [12], Y.Y. Lo and E. Macaro [20] pointed out the target subject teachers lack language competence. Such scientists as K. Kashiwagi and J. Tomecsek [15], A. 
Llinares [19], J. Kowal and G. Paliwoda-Pękosz [16] studied the use of CLIL from a different perspective. They have developed recommendations that should help to overcome the weakness of the method. The experts recommend engaging target subject teachers who have certificates confirming their level of foreign language proficiency. As the advantages of this method, D. Chostelidou and E. Griva [6], K. Kashiwagi and J. Tomecsek [15], N. Piesche, K. Jonkmann, Ch. Fiege, J.-U. Kebler [29] noted the increasing of students' motivation to master is not only related to a foreign language but also the discipline taught in that language.

This idea is supported by the experimental studies conducted by P. Mehisto and D. Marsh [24], A. Doiz, D. Lasagabaster, J.M. Sierra [11], L. K. Sylvén, A. S. Thompson [33], D. L. Banegas [3], C. Altıner [1], K. Vlasenko, O. Chumak, I. Sitak, I. Lovianova, O. Kondratyeva [38]. The scientists found that raising students' motivation comes from integrating their learning experiences. The scientists argue that the interest and motivation for learning a second discipline arise in connection with its purposeful use when presenting the language content. In addition, motivation is provided through the dynamics of lessons during which the materials are discussed. Thus, students become active participants in the process, so they are ready to learn.

Upon reviewing the scientists' research materials, we focused on this approach when developing a course on elementary mathematics for 1-st year technical specialty students. English was chosen as a foreign language. The idea of applying the method was approved during the 16th annual international conference on Hands-on Science, HSCI 2019 [37]. The course developers gave an account of the method application and the results of forming and raising students' motives for studying mathematics. Following E. Karpova [14], we considered the motives by dividing them into four groups.

Achievement motives. Such motives help manage activities, by providing for lasting results through the satisfaction of success.

Cognitive motives. This group of motives provokes activities aimed at gaining new knowledge. The feeling of satisfaction from discovering new things helps to derive pleasure from the activity.

Learning motives. This group of motives provides gaining satisfaction from improving ways of learning.

Learning and vocational motives. Such motives are based on a sense of satisfaction from a prospective professional career.

Taking prior research into account, the purpose of the article is to study the impacts of using CLIL-approach on students' learning motivation for mathematical disciplines at higher technical education institutions of Ukraine. We conducted an experiment with a view to select the CLIL model, decide on the subject content of the elective course, to systematize elementary mathematics tasks, and to consider methods that can be used to support teaching mathematics in English and to enhance students' motivation.

\section{Materials and Methods}

When choosing a mathematical discipline, we decided on Elementary Mathematics, because most of its concepts and procedures are fundamental for studying special disciplines at a technical university. When selecting a model for the implementation of the CLIL-approach, we opted for the C2 CLIL (Adjunct CLIL) model, which focuses on the education and mastering mathematical terminology in English, as well as developing skills to use language in practical activities for career development.

252 students of Donbass State Engineering Academy, the Institute of Chemical Technologies (the town of Rubizhne) of the East Ukrainian Volodymyr Dahl National University, Donbas National Academy of Civil Engineering and Architecture, Cherkasy State Technological University participated in the experiment between 2016 and 2019. Both mathematics and English teachers were involved in the preparation and development of the course. 8 teachers and 16 students' groups took part in the experiment. Each of the teachers acquainted themselves with the basics of CLIL-approach in advance. All mathematics teachers had certificates on English proficiency no lower than level B2 according to CEFR established by the Council of Europe.

The experimental groups (EG) (12 to 15 students) were formed from students who had thirst for learning the language but not for Math. The initial level of the students' motivation was determined with the use of the adapted questionnaire by R. M. Ryan and E. L. Deci [31]. The control groups (CGs) were chosen so that the difference between the levels of the students' motivation in the EG and CG was not significant. The analysis was conducted with the help of the Distribution-free Test of Fit $\chi^{2}$.

Before the introduction of CLIL, the teachers of mathematics and English planned curricular topics together so that both benefit from each other's area of expertise. In the course of the experiment, it was a fixed program. The syllabus consisted of 6 classes 45 minutes each. Having chosen the topics, we developed the training materials to consider arithmetic operations, fractions, the number raised to a power, quadratic roots, the real numbers, equations, and inequations. While planning each tutorial, the teachers pondered on the learning outcomes and focused on what the learners would be able to achieve, which features the learner-centered approach. One class per week was planned for each of the two groups in parallel. Before studying each topic, the math teacher would introduce the students learning outcomes. Most of the teachers preferred writing learning objectives on the board so that the students were clear about what they 
should have achieved by the end of the lesson. To prepare for tutorials, the English teacher helped select content-obligatory language to present learners with vocabulary and different tasks that demand the same use of concepts to revisit learning.

At the beginning, the experiment for both students and teachers encountered a number of daunting challenges. The teachers had to figure out how long it might take to solve tasks, how well the students could understand explanations and instructions, what type of support students needed for tackling tasks. Some students needed support in order to understand mathematical concepts while others needed more support while communicating about these concepts. Therefore, the teachers worked out the strategies for both content support and language support. For example, before doing the tasks, the teacher presented some sentence starters to the students in order to support their reasoning skills (Table 1).

Table 1. An example of sentence starters to support students' reasoning skills

\begin{tabular}{|c|c|c|}
\hline We found $\mathrm{tl}$ & the graph equation & is ___because \\
\hline \multicolumn{3}{|c|}{$\begin{array}{l}\text { We found that the equation } \mathrm{y}=x \text { is linear because the coordinates } \\
\text { make a straight line. } \\
\text { We found that the equation } \mathrm{y}=\sqrt{x} \text { is non-linear because the } \\
\text { coordinates make a curved graph. }\end{array}$} \\
\hline
\end{tabular}

Thus, the differentiation of the students was based on inputs, tasks, and supports. While the low-achieving students solved fewer tasks or used simpler numerical content, higher-performing students received more difficult tasks to develop their thinking and reasoning skills. This is when Information and Communication Technologies (ICT) were beneficial for online learning activities such as self-study and fact-finding.

At the beginning of the CLIL course, the teachers adhered to the idea of the importance to follow simple explanations with the use of active teaching methods. Frequently the activation of the prior knowledge started with an oral brain storm involving the whole class so that the students had the opportunity to communicate concepts and vocabulary they already know. While introducing the subject-specific language and vocabulary, mathematics teachers used tasks of different types. In selecting the tasks, the teachers found out which ones contribute to student motivation and student-teacher interaction, as well as develop thinking, reasoning skills, and mental agility. We pieced together the tasks for different classes. We used the tasks on completing diagrams and crosswords, classifying concepts, filling gaps, comparison and contrasting, multiple choice, domino games, label match, jigsaw, writing essay, etc. Examples of the problems related to real-life contexts helped to increase students' interest in Math. What is more, such tasks helped them solve math issues more confidently.

The critical question was which tasks need language support. Therefore, twice the teacher offered the students a short questionnaire, which helped to improve the organization of selecting tasks for tutorials.

What type of tasks do you enjoy working with?

Assess the complexity of the tasks.

What kind of tasks helps you learn Maths in English?

When answering these questions, the students stressed the need for using simpler words and mnemonics, engaging diagrams, games, pictures, combining vocabulary and illustrations, drawing more explanations, familiarizing themselves with more complex mathematical concepts.

In the course of the class, we interleaved up to three types of activity. To maintain activities on reading comprehension, writing, listening comprehension, and oral expression, the mathematics teachers used multimedia technologies. Multimedia support demonstrated explanation vocabulary, activation of prior knowledge, evaluation of prior knowledge task, consolidation activity, etc. During the actualization of the prior knowledge, multimedia training helped to prepare the students for the next phase of learning new material. In the process of teaching new material, such support helped to provide a certain degree of illustrative during the new material presentation by modeling problem situations. At the skills formation stage, multimedia learning support facilitated the creation of the conditions for students' optimal transition to higher levels of mastering new learning material. In addition, the support made it possible to check the quality of mastering the learning material, its analysis, and systematization. Among the effective types of assessment, we chose a performance assessment. This kind of assessment engaged students in demonstrating their knowledge of mathematical concepts and language. They had the possibility to explain to the others how to solve certain types of tasks and give elucidations of some mathematical concepts. In addition to it, this kind of assessment helped to evaluate the development of communicative and cognitive skills as well as attitude towards learning.

For some classes, communicating activity could be short in time, when students had 3-4 minutes to talk with a partner on the subject. This activity could be longer. In this case, the students had 10 minutes to communicate with a group of partners, with each partner having to express their opinion. Not only did we assess the students while they were solving the tasks, writing essays, doing communicating activity but we also used peer assessment

\section{Results}

The experiment lasted from 2016 - 2017 to 2018 2019 academic years. It involved the students of Donbass State Engineering Academy (75 persons), the Institute of Chemical Technologies (the town of Rubizhne) of the East Ukrainian Volodymyr Dahl National University (58 persons), Donbas National Academy of Civil Engineering and Architecture (60 persons), Cherkasy State 
Technological University (59 persons). The gender compositions of the EG and the CG were almost proportional. In the EG girls made up $26 \%$, in the CG $24.5 \%$.

The analysis of the initial level of the students' motivation to learn mathematical disciplines based on adapted questionnaire by R.M. Ryan and E.L. Deci, [31] showed no significant difference between the EG and the
CG students' motivation levels. At the end of the experiment, the CG and the EG students completed the same questionnaire again (Table 2).

According to the test, the students were to rate each affirmation from 0 to 10 , depending on how much they agreed with the given statement, where 0 - completely disagree, 10 - completely agree.

Table 2. The average results of the students' responses in the experimental and control groups after the experiment

\begin{tabular}{|c|c|c|c|c|}
\hline \multirow{3}{*}{ Statements } & \multicolumn{4}{|c|}{$\begin{array}{l}\text { The average point of the students' attitude to the } \\
\text { statement }\end{array}$} \\
\hline & \multicolumn{2}{|c|}{$\begin{array}{c}\text { At the beginning of the } \\
\text { experiment }\end{array}$} & \multicolumn{2}{|c|}{$\begin{array}{c}\text { At the end of the } \\
\text { experiment }\end{array}$} \\
\hline & $\mathrm{EG}(125)$ & CG(127) & EG(125) & $\mathrm{CG}(127)$ \\
\hline Achievement Motives & 5.01 & 4.5 & 6.78 & 4.49 \\
\hline 1. I'm interested in my progress in mathematics more than in other disciplines & 5.21 & 4.65 & 7.16 & 4.93 \\
\hline 2. I like talking to my teachers on math issues during classes & 4.76 & 4.35 & 6.68 & 3.78 \\
\hline 3. I like doing problems on proofs & 5 & 4.95 & 6.15 & 4.68 \\
\hline 4. I always look for additional materials for the class & 4.98 & 3.75 & 6.88 & 4.69 \\
\hline 5. When preparing for classes, I always do more problems than I'm assigned & 5.1 & 4.8 & 7.03 & 4.37 \\
\hline Cognitive Motives & 5.41 & 5.57 & 7.81 & 5.63 \\
\hline 6. I like giving correct answers to a teacher's questions & 5.28 & 5.36 & 9.03 & 5.91 \\
\hline $\begin{array}{l}\text { 7. Successful use of new knowledge in mathematics and positive results can help boost } \\
\text { my self-esteem }\end{array}$ & 5.65 & 5.59 & 7.68 & 4.7 \\
\hline 8. I like trying new things & 6.18 & 5.2 & 6.75 & 5.68 \\
\hline 9. I like when a teacher or my group mates mark me out if I do math problems correctly & 4.57 & 6.17 & 7.18 & 6.69 \\
\hline $\begin{array}{l}\text { 10. My academic achievements make my family and friends happy, and it brings me } \\
\text { joy and satisfaction }\end{array}$ & 5.37 & 5.53 & 8.41 & 5.17 \\
\hline Learning Motives & 5.12 & 4.62 & 8.71 & 4.49 \\
\hline 11. I would like to know math better than my group mates & 5.07 & 5.16 & 8.83 & 3.37 \\
\hline 12. I do well academically because I want to get a stipend & 5.35 & 5.59 & 7.58 & 4.48 \\
\hline 13. I try to make notes in a copybook during classes & 4.21 & 4.05 & 9.75 & 5.24 \\
\hline 14. I agree that mathematics is no less important than vocational subjects & 5.58 & 3.17 & 9.18 & 4.19 \\
\hline $\begin{array}{l}\text { 15. Mathematics is my favorite subject, and I am always interested in learning } \\
\text { something new }\end{array}$ & 5.39 & 5.13 & 8.21 & 5.17 \\
\hline Learning and Vocational Motives & 4.26 & 4.38 & 7.67 & 4.54 \\
\hline 16. I would like to have a profession related to the use of mathematical tools & 3.11 & 4.92 & 7.16 & 4.74 \\
\hline $\begin{array}{l}\text { 17. I like applying mathematics knowledge during classes on vocationally-oriented } \\
\text { subjects }\end{array}$ & 4.76 & 4.37 & 9.68 & 3.32 \\
\hline 18. I would like to study mathematics in English & 4.35 & 4.88 & 6.15 & 4.58 \\
\hline $\begin{array}{l}\text { 19. I am interested in certain processes, and I always try to gain some insight into their } \\
\text { nature and mathematical interpretation }\end{array}$ & 3.98 & 3.75 & 8.28 & 4.69 \\
\hline $\begin{array}{l}\text { 20. I am not used to being satisfied with what I have already achieved, I prefer to try } \\
\text { new things }\end{array}$ & 5.1 & 3.98 & 7.08 & 5.37 \\
\hline
\end{tabular}


Using the chart, we compared the questionnaire results (Fig.1).

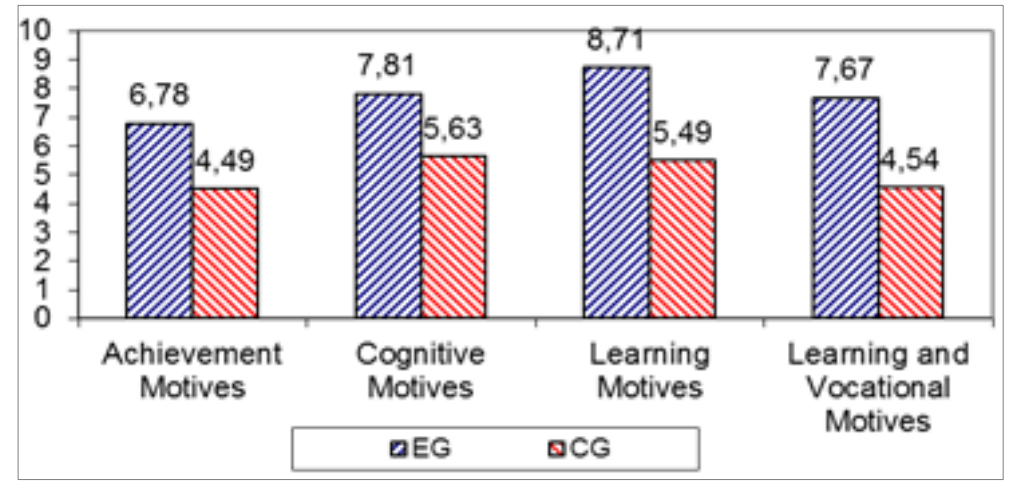

Figure 1. Comparative results in the experimental and control groups after the experiment

According to the results of the experiment in the EG compared to the CG, motivation is higher for all the indicators by an average of $27.15 \%$. The average point of achievement motives increased by 2.29 points, cognitive motives by 2.22 points, learning motives by 3.22 points, learning and vocational motives - by 3.13 points.

Also, using the chart, we compared the results of surveying the experiment group before and after the experiment.

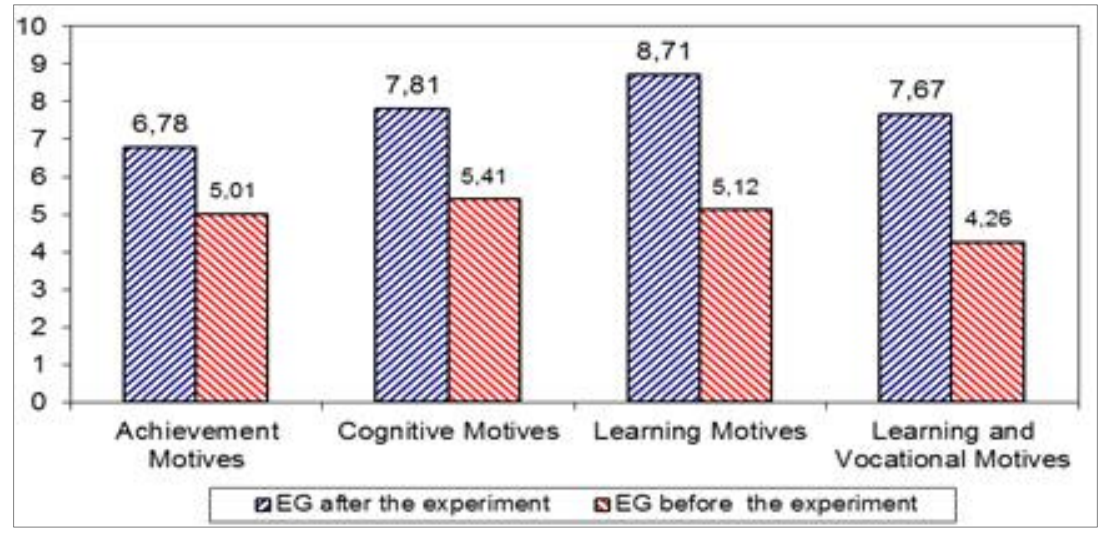

Figure 2. Comparative results in the experimental group before and after the experiment

In the EG after the experiment, there is an increase in motivation for all the indicators by an average of $27.93 \%$. The average point of achievement motives increased by 1.77 points, cognitive motives - by 2.4 points, learning motives by 3.59 points, learning and vocational motives - by 3.41 points.

We also compared the results of improving the male and female students' motivation in the experimental group after the experiment.

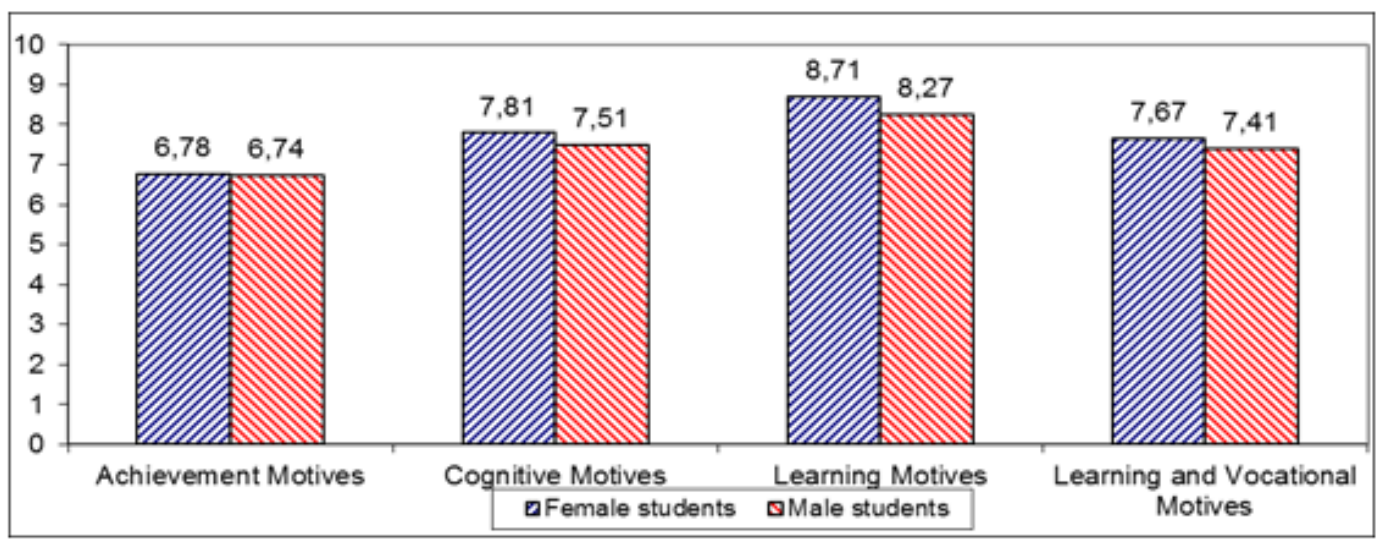

Figure 3. Comparative results of male and female students' motivation in the experimental group before and after the experiment 
Table 3. Calculations of the Fitting Criterion

\begin{tabular}{|c|c|c|c|c|c|}
\hline \multirow{2}{*}{ Motives } & \multicolumn{2}{|c|}{ EG Results $\left(\mathrm{n}_{1}=125\right)$} & \multicolumn{2}{|c|}{ CG Results $\left(\mathrm{n}_{2}=127\right)$} \\
\cline { 2 - 6 } & $\begin{array}{c}\text { Before the } \\
\text { experiment }\end{array}$ & $\begin{array}{c}\text { After the } \\
\text { experiment }\end{array}$ & $\begin{array}{c}\text { Before the } \\
\text { experiment }\end{array}$ & $\begin{array}{c}\text { After the } \\
\text { experiment }\end{array}$ \\
\hline Achievement Motives & 5.01 & 6.78 & 4.5 & 4.49 \\
\hline Cognitive Motives & 5.41 & 7.81 & 5.57 & 5.63 \\
\hline Learning Motives & 5.12 & 8.71 & 4.62 & 4.49 & 0.00087732 \\
\hline Learning and Vocational Motives & 4.26 & 7.67 & 4.38 & 4.54 \\
\hline \multicolumn{2}{|c|}{ The point of the test } \\
\hline
\end{tabular}

We can observe that in the EG the motivation is uneven on the gender basis for all the indicators, except the achievement motives. Thus, the assessment of cognitive motives in male students is higher by 0.6 points, while for learning and vocational motives the average value in girls is higher by 0.88 and 0.52 points respectively.

For statistical proving of the calculation results, we chose Distribution-free Test of Fit $\chi^{2}$. For significance value $\alpha=0.05$ and the degree of freedom $v=4-1=3$ the critical point of the test statistics $\mathrm{T}$ equals $x_{1-\alpha}=$ 7.815. Table 3 shows the calculation of the criterion using Microsoft Excel spread sheets.

Thus, $T>x_{1-\alpha}(12.34>7.815)$. According to the decision rale, the affirmation about the positive impact of the introduced course of Elementary Mathematics on the basis of CLIL-approach on technical specialty students of Ukrainian universities can be made.

\section{Discussion}

Bringing out CLIL-approach as the most promising one for use in teaching mathematical disciplines is justified. C.R. Rizzo, N. Carbajosa Palmero [30], D. Chostelidou and E. Griva [7] explain the benefits of implementing the approach, by pointing to the possibility of integrating the means of teaching the subject, the mastery of which is accompanied by language learning. J. Novotná and M. Hofmannová [27] indicate the activation of a wide range of cognitive processes while studying a non-linguistic subject with the application of CLIL. T. Somers and A. Llinares [32] study the impact of technology on students' motivation, pointing out that most studies are on motivation to learn a foreign language. To fill this gap, we introduce CLIL into the teaching of mathematical discipline to students of Ukrainian higher education institutions.

The analysis of such blogs and on-line platforms as CLIL media, Practical Tips\&Tricks for Every CLIL Teacher [9], My Maths Blog - CLIL contents [26], CLIL in Ukraine [8], Teaching English [34], Teaching Mathematics through English [35] and the results of research conducted by a creative team led by T. Somers and A. Llinares [32] proved the appropriateness of our choice of this technology to improve students' motivation for studying Elementary Mathematics. We have also found substantiation for this in the training on achievement motivation initiated by D.C. Mc Clelland [23] and J.W. Atkinson [2]. The scientists brought out the factors of developing motivation through the formation of a system of qualities related to achievement, self-analysis, development of optimal goal-setting tactics, interpersonal support. The actualization of these factors we exercised through psychological means related to the experiment participants' own activity, their enjoyment from learning English.

In addition, considering the CLIL materials [18] and the academic practices of implementing the approach [21], we decided on a CLIL model. Model C2, defined as Adjunct CLIL, means using language as an assistant to develop higher-order thinking [10] and to ensure the enjoyment of improving learning methods. Accepting the recommendations of the Cambridge English [5] and Teaching English [34] platforms, which state that language skills can be a means of mastering the content of another discipline, we propose to integrate the skills of both disciplines while developing the syllabus. We have also taken into account the recommendations of S.A. Montalto, L. Walter, M. Theodorou, K. Chrysanthou [25] on enabling a target discipline teacher to select language means that can help implement the content of learning sessions in Elementary Mathematics. However, during the experiment, we adhered to the idea of the importance of constant collaboration between Mathematics and English teachers. We also agree with the views of J. Novotná and M. Hofmannová [27], K.V. Vlasenko, I.V. Lovyanova, O.O. Chumak, I.V. Sitak, T.S. Kalashnykova [36] on the differentiated approach to inputs, tasks, and supports for students during classes and the choice of methods, forms and learning aids that contribute to the visual and auditory perception of the educational material by the students. When selecting the tasks, we analyzed the recommendations of CLIL media, Practical Tips\&Tricks for Every CLIL Teacher [9] platforms and chose to focus on those, that help a teacher create a problem, promote student motivation and student-teacher interaction.

\section{Conclusions}

The analysis of scientific and methodical literature 
proves the relevance of the study of the issues in integrating English and Elementary Mathematics for improving students' motivation for studying mathematical disciplines.

The joint activities of English and Mathematics teachers during the implementation of CLIL at technical universities in Ukraine facilitated the development of the requirements and recommendations, which contributed to the positive dynamics of achievement motives, cognitive motives, learning, and vocational motives.

1. Mathematics teachers engaged in teaching Elementary Mathematics in English are required to have language proficiency no lower than the Council of Europe Level B2.

2. English teachers should offer ongoing support to Mathematics professors on applying theory and methodology of teaching English.

3. The initial level of English proficiency for those students who are willing to attend the course must meet the minimum B2 level. The appropriateness of using a differentiated approach to the experiment participants was confirmed.

4. Consolidated activities of all the teachers engaged in teaching in experimental groups should be targeted at developing the syllabus and "bank" of learning support materials. The teachers participating in the experiment should be introduced upfront to all the materials of the experiment. For this purpose, the teachers should be given a series of seminars and training, during which all questions and problems should be agreed on. Searching for answers to any questions and reviewing programs and materials should be conducted in collaboration with all the teachers engaged in the experiment.

5. The first action item of the experiment should be surveying the student with the questionnaire by R.M. Ryan and E.L. Deci [31] to assess the level of their motivation to learn Mathematics and confirm the homogeneity of the experimental and control groups. Students in both groups should work with the same materials on Elementary Mathematics, using the same active learning methods and aids.

6. The implementation of the method can be carried out under the $\mathrm{C} 2$ model, following the appropriate steps according to D. Coyle, P. Hood, M. Marsh [10]. Each of them involves assessing, developing, and providing different types of student support during studies.

7. After studying each topic, the teacher should offer students a short questionnaire, the questions in which will help improve the organization of task selection and support for students.

The conformity with these recommendations and requirements during the implementation of the CLIL-approach for the EG students contributed to a positive increase in the motivation levels of the four groups by an average of $27.93 \%$. The result proving the increase of the students' motivation in the CG is much lower and differs in all groups of motives.

As the follow-up research directions, we consider the creation of a section at Higher School Mathematics Teacher [13] learning platform that will present the developed materials for implementing CLIL.

\section{REFERENCES}

[1] Altıner, C. (2018). Preparatory school students' English language learning motivation: A sample from Turkey. Universal Journal of Educational Research, 6(8), pp. 1729 1737. https://doi.org/10.13189/ujer.2018.060814

[2] Atkinson, J. W. (1964). An introduction to motivation. Princeton, NJ: Van Nostrand.

[3] Banegas, D.L. (2016). The integration of content and language as a driving force in the EFL lesson. Online available from https://www.academia.edu/3586490/The_in tegration_of_content_and_language_as_a_driving_force_i n_the_EFL_lesson

[4] Bystray, Y., Belova, L., Vlasenko, O., Zasedateleva, M., Shtykova, T. (2018). Development of second-language communicative competence of prospective teachers based on the CLIL Technology (From the experience of a pedagogic project at a Department of History). Revista Espacios, 39 (52), p. 12 . Online available from https://www.revistaespacios.com/a18v39n52/18395212.ht $\mathrm{ml}$

[5] Cambridge Assessment English (2019). Online available from https://www.cambridgeenglish.org/teaching-english/t eaching-qualifications/tkt/about-tkt/

[6] Chostelidou, D. \& Griva, E. (2011). English language teachers' conceptions and attitudes to multilingual development in education. Procedia - Social and Behavioral Sciences, 15, pp. 1780 - 1785. Online available from https://www.researchgate.net/publication/251713578_Engl ish_Language_Teachers'_conceptions_and_attitudes_to_m ultilingual_development_in_Education

[7] Chostelidou, D. \& Griva, E. (2014). Measuring the effect of implementing CLIL in higher education: An experimental research project. Procedia - Social and Behavioral Sciences, 116, pp. 2169 - 2174. https://doi.org/10.1016/j.sbspro.201 4.01 .538

[8] Goethe-Institut Ukraine. CLIL in Ukraine (2019). Online available from https://www.goethe.de/ins/ua/uk/spr/unt/ku $\mathrm{m} / \mathrm{ciu} . \mathrm{html}$

[9] CLIL media. Practical tips \& tricks for every CLIL teacher. Online available from https://www.clilmedia.com/clil-mat hematics-more-ideas-to-try-out-in-your-lesson/

[10] Coyle, D., Hood, P., Marsh, M. (2010). Content and language integrated learning. Cambridge: Cambridge University Press. Online available from https://abdn.pure.e lsevier.com/en/publications/content-and-language-integrat ed-learning 
[11] Doiz, A., Lasagabaster, D., Sierra, J. M. (2014). CLIL and motivation: The effect of individual and contextual variables. Language Learning Journal, 42(2), pp. 209 - 224.

[12] Hajer, M. \& Maaike, L. (2000). Creating a language-promoting classroom: content area teacher sat work. In Hall, Joan Kelly and Lorrie Stoops Verplaetse (eds.). Second and foreign language learning through classroom interaction. Mahwah N.J. and London: Lawrence Erlbaum Associates, pp. 265 - 285.

[13] Higher School Mathematics Teacher (2019). Online available from http://formathematics.com/

[14] Karpova, E. V. (2012). Achievement motivation in the structure of motivational support of the educational activity and its diagnostics technique. Yaroslavl Pedagogical Bulletin. 2, (II), pp. 328-333. Online available from http://vestnik.yspu.org/releases/2012_2pp/71.pdf [in Rus.]

[15] Kashiwagi, K. \& Tomecsek, J. (2015). How CLIL classes exert a positive influence on teaching style in student centered language learning through overseas teacher training in Sweden and Finland. Procedia - Social and Behavioral Sciences, 173, pp. 79-84. https://doi.org/10.101 6/j.sbspro.2015.02.034

[16] Kowal, J. \& Paliwoda-Pękosz, G. (2017). ICT for global competitiveness and economic growth in emerging economies: Economic, cultural, and social innovations for human capital in transition economies. Information Systems Management, 34(4), pp. 403-425. https: //doi.org/10.1080/02681102.2014.1003521

[17] Kulyk, O. (2017). Applying CLIL techniques to teach analytic philosophy in English. Presented at the All-Ukraine Scientific Conference "Education and Science in the Context of Global Transformations", Dnipro, Ukraine. Online available from https://www.academia.edu/3555001 9/Applying_CLIL_techniques_to_teach_analytic_philosop hy_in_English

[18] Langé, G. \& Bertaux, P. (2002). TIE-CLIL professional development course. M.I.U.R., Direzione regionale della Lombardia.

[19] Llinares, A. (2015). Integration in CLIL: a proposal to inform research and successful pedagogy. Language, Culture and Curriculum, 28(1), pp. 58-73. https: //doi.org/10.1080/07908318.2014.1000925

[20] Lo, Y.Y. \& Macaro, E. (2015). Getting used to content and language integrated learning: what can classroom interaction reveal? The Language Learning Journal, 43(3), pp. 239-255. https://doi.org/10.1080/09571736.2015.1053 281

[21] Manning, A., Nukui, C., Fava-Verde, A., Griffiths, P. et al. (2015). Transferable academic skills kit (TASK). University of Foundation Study: Garnet Education.

[22] Marsh, D. (2002). CLIL/EMILE - The European Dimension. University of Jyväskylä, Finland. Online available from https://jyx.jyu.fi/bitstream/handle/123456789/47616/david _marsh-report.pdf?sequence $=1 \&$ is Allowed $=y$

[23] McClelland, D.C. (1971). Assessing human motivation. General Learning Press.

[24] Mehisto, P. \& Marsh, D. (2011). Approaching the economic, cognitive and health benefits of bilingualism: Fuel for CLIL. In Content and Foreign Language Integrated Learning, 36. Bern: Peter Lang.

[25] Montalto, S. A., Walter, L., Theodorou, M., Chrysanthou, K. (2014). The CLIL guidebook. Lifelong Leaning Program. Online available from https://www.languages.dk/archive/cl il4u/book/CLIL\%20Book\%20En.pdf

[26] My Math Blog - CLIL contents (2008). Online available from https://theblogmath.wordpress.com/

[27] Novotná, J. \& Hofmannová M. (2000). CLIL and mathematics education. Online available from https://www .researchgate.net/publication/228491266_CLIL_and_math ematics_education

[28] OECD (2017). PISA 2015 Results (Volume III): Students'Well-Being. PISA, OECD Publishing, Paris. Online available from https://www.oecd-ilibrary.org/docse rver/9789264273856-en.pdf?expires=1575888901\&id=id $\&$ accname $=$ guest $\&$ checksum $=0531528870$ D8224A76DF9 A06B91FB4A9

[29] Piesche, N., Jonkmann, K., Fiege, C., Keßler, J.-U. (2016). CLIL for all? A randomised controlled field experiment with sixth-grade students on the effects of content and language integrated science learning, Learning and Instruction, 44, pp. 108-116. https://doi.org/10.1016/j.learn instruc.2016.04.001

[30] Rea Rizzo, C. \& Carbajosa Palmero, N. (2014). CLIL Teacher training at the UPCT: present and future within the EHEA. REDU. Revista de Docencia Universitaria, [S.1.], 12 (4), pp. 377-393. https://doi.org/10.4995/redu.2014.5628

[31] Ryan, R. M. \& Deci, E. L. (2001). On happiness and human potentials: A review of research on hedonic and eudaimonic well-being. Annual Review of Psychology, 52, pp. 141-166. Online available from https://psych415.class.uic.edu/Readi ngs/Ryan,\%20Happiness\%20-\%20well\%20being,\%20Ann RevPsy,\%202001.pdf

[32] Somers, T. \& Llinares, A. (2018). Students' motivation for content and language integrated learning and the role of programme intensity. International Journal of Bilingual Education and Bilingualism. https://doi.org/10.1080/13670 050.2018 .1517722

[33] Sylvén, L. K. \& Thompson, A. S. (2015). Language learning motivation and CLIL. Journal of Immersion and Content-Based Language Education, 3(1), pp. 28-50. https://doi.org/10.1075/jicb.3.1.02syl

[34] Teaching English. British Council (2017). Online available from https://www.teachingenglish.org.uk/

[35] Teaching Mathematics through English - Teaching English through Mathematics (2018). Online available from https://clilmaths.jimdo.com/about-clil/clil-aproach/

[36] Vlasenko, K.V., Lovyanova, I.V., Chumak, O.O., Sitak, I.V., Kalashnykova, T.S. (2019). The formation of foreign language competence of engineering students through CLIL-method. Revista Dilemas contemporáneos: Educación, Política y Valores. Year VIII, Special Edition, no.:68, November 2019. Online available from https://dile mascontemporaneoseducacionpoliticayvalores.com/_files/ 200006243-e84c1e84c3/EE\%2019.11.68\%20La\%20forma ci\%C3\%B3n\%20del\%20conocimiento\%20de\%20lenguas 
$\% 20$ extranjeras $\% 20 \mathrm{de} . . . . . \mathrm{pdf}$.

[37] Vlasenko, K., Lovianova, I., Sitak, I., Chumak, O., Kondratyeva, O. (2019). Learning platform as one of the ways to improve the professional qualification of mathematical disciplines teachers at higher technical educational institutions, Hands-on Science. Innovative Education in Science and Technology, pp.164-166, Online available from http://hsci.info/hsci2019/images/pdfs/PRO CEEDINGS_HSCI2019.pdf

[38] Vlasenko, K., Chumak, O., Sitak, I., Lovianova, I., Kondratyeva, O. (2019). Training of mathematical disciplines teachers for higher educational institutions as a contemporary problem, Universal Journal of Educational Research, 7(9), pp. 1892-1900. https://doi.org/10.13189/uj er.2019.070907

[39] Vollmer, H. J., Heine, L., Troschke, R., Coetzee, D., Küttel, V. (2006). Subject-specific competence and language use of CLIL learners: The case of geography in grade 10 of secondary schools in Germany. Paper presented at the ESSE8 Conference, London, UK, pp. $22-25$. 